\title{
GENERICALLY SPEAKING, A SURVEY ON NEOGENE RODENT DIVERSITY AT THE GENUS LEVEL IN THE NOW DATABASE
}

\author{
LARS W. VAN DEN HOEK OSTENDE ${ }^{1, *}$, MELIKE BILGIN ${ }^{2,1}$, YANELL BRAUMULLER ${ }^{1}$, JÁNOS HÍR ${ }^{3}$, PETER \\ JONIAK ${ }^{2}$, SÍLVIA JOVELLS-VAQUÉ ${ }^{4}$, PABLO PELÁEZ-CAMPOMANES ${ }^{5}$, JÉRÔME PRIETO ${ }^{6}$, PANAGIOTIS \\ SKANDALOS ${ }^{7,1}$, ISAAC CASANOVAS-VILAR ${ }^{4}$
}

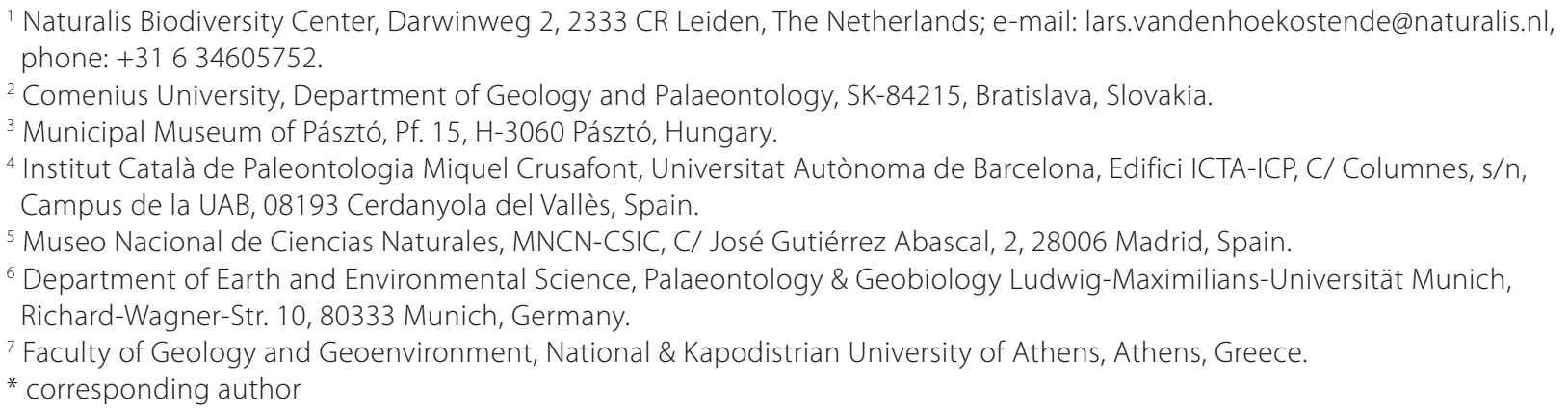

Van den Hoek Ostende, L. W., Bilgin, M., Braumuller, Y., Hír, Y., Joniak, P., Jovells-Vaqué, S., Peláez-Campomanes, P., Prieto, J., Skandalos, P., Casanovas-Vilar, I. (2020): Generically speaking, a survey on Neogene rodent diversity at the genus level in the NOW database. - Fossil Imprint, 76(1): 118-127, Praha. ISSN 2533-4050 (print), ISSN 2533-4069 (online).

\begin{abstract}
Over the last half a century, a massive amount of data has been gathered on Neogene rodents of Europe. Using the NOW database, we analysed changes in generic diversity during the Neogene and the beginning of the Quaternary. Studies as the present are useful for exploring major changes in diversity, but the pitfalls are many and varied. Whereas the quality of the fossil record is good, there are notable exceptions. Within our dataset, MN 1, MN 12 and MN 17 stand out for the limited number of localities available and the record of the eastern Mediterranean is clearly as yet poorer than that from central Europe and the Iberian Peninsula. The record can be influenced by incomplete faunal lists, outdated literature and unresolved taxonomies. In addition, the use of the MN system presumably obscures patterns, as it often does not allow for a co-eval comparison between various regions. Reconstruction of major patterns starts with the understanding of basic data. Despite all these limitations the results of this work indicate that the record for central Europe consistently shows higher diversity than lower latitudes. The highest peak in diversity is found in MN 15, but the record of the Iberian Peninsula shows no increase at that time. The rodent diversity is surprisingly constant during most part of the Neogene, the stronger variations being related to the diversification of the murinae and arvicolinae groups and decline of the cricetine.
\end{abstract}

Key words: palaeobiogeography, Europe, Rodentia, Miocene, Pliocene, bias

Received: April 3, 2019| Accepted: December 20, 2019| Issued: November 9, 2020

\section{Introduction}

Gerhard Storch published, apart from his work on recent mammals, a large number of important papers on Neogene rodents (e.g., Storch 1978, 1996, Storch and Qiu 1990, 2002). While older studies including small mammals date back to the $19^{\text {th }}$ century (e.g., von Meyer 1846, Lartet 1851), the field of micromammal palaeontology developed during the first half of the $20^{\text {th }}$ century (e.g., Schlosser 1902, Schaub 1925, Dehm 1935, Schreuder 1943, 1950, Crusafont Pairó et al. 1948) and became a separate subdiscipline in the 1960s under the guidance of modern pioneers such as Volker Fahlbush, Hans de Bruijn, Pierre Mein and Thijs Freudenthal.
On the other side of the Iron Curtain, still very much in place at that time, Miklós Kretzoi, Oldřich Fejfar and Kazimierz Kowalski started their impressive careers on small mammal palaeontology. As such, Storch was part of the second generation, that started publishing in the 1970s. This and later generations amassed a large amount of data, which enabled us to develop detailed micromammal stratigraphies (Abdul Aziz et al. 2008, 2010, Van der Meulen et al. 2012, Casanovas-Vilar et al. 2011, 2016, García-Paredes et al. 2016, Prieto and Rummel 2016, Hír et al. 2016, 2017), play a major role in the biochronological MN system (Mein 1975, 1990, De Bruijn et al. 1992, Agustí et al. 2001) and discern cross-continental patterns (Van der Meulen et al. 
2011, 2012, Casanovas-Vilar et al. 2010, Furió et al. 2011).

There can be no doubt that the legacy of the Storch generation is strong. Not only is the vast amount of data gathered over the last 60 years used to refine the rodent stratigraphy and taxonomy, but the record is also used to tackle modern questions on climate change and biodiversity (e.g., Van Dam and Weltje 1999, Montuire et al. 2006, Blanco et al. 2018). The record from the Calatayud-Teruel basin, one of the finest in the world, was even used to provide a direct link between changes in rodent diversity and astronomic forcing (Van Dam et al. 2006). Given the immense amount of data gathered, databases and complex numerical analyses play an ever increasing role in deciphering the small mammal record.

The primary database for fossil mammals is the publically available New and Old Worlds (NOW) database. Peláez-Campomanes and Van der Meulen (2009) tested the quality of the database, focussing on the homogeneity of the small mammal record vs. the large mammal record in the database. Their main conclusion was that, other than the large mammals, the small mammal record was largely homogeneous, the record for $\mathrm{MN} 12$ being somewhat problematic. In this paper, we give an overview of the Neogene and early Pleistocene rodents on the genus level. The study of Peláez-Campomanes and Van der Meulen (2009) was based on the European records west of 20 degrees longitude. Here, we use a somewhat wider record to compare major patterns in generic diversity in different regions in Europe. Our aims are twofold. On one hand, we want to explore the viability of the record. On the other hand, we aim to discern the major pattern in rodent biodiversity focusing on generic diversity in relation to palaeogeography and rodent groups of taxonomical high-rank.

\section{Material and methods}

A dataset was downloaded from the NOW database (The NOW Community, February 2019) selecting all Rodentia from MN 1 to MN 17. All non-European occurrences (with the exception of Anatolian localities) were deleted from the Excel-file. Occurrences were sorted per MN unit. Localities for which a range of more than one $\mathrm{MN}$ unit was given, were not included. The data were ordered per region, following the subdivision of Casanovas-Vilar et al. (2010), viz. Iberian Peninsula (IB; Portugal, Spain), central Europe (CE; France, Switzerland, Germany, Poland, Czech Republic, Austria, Slovakia, Hungary, Italy, The Netherlands) and eastern Mediterranean (EM; Ukraine, Moldova, Romania, Serbia, Montenegro, Bulgaria, Greece, Turkey). Subsequently, occurrences of rodent genera per $\mathrm{MN}$ unit were extracted for each of the regions.

The choice of using MN units is one of convenience. The great majority of the Eurasian localities in the NOW database have been assigned to an $\mathrm{MN}$ unit or to a range of units. However, the MN system is based on a sequence of reference localities or more commonly on the appearance of taxa. As first occurrences of these taxa differ in different regions, the system inherently is prone to diachronies (Van der Meulen et al. 2011). These diachronies may be quite strong. For instance, MN 6 in central Europe is coeval with the later part of MN 5 in the Iberian Peninsula.
The Mediterranean region features quite a few rodent genera which are insular endemics (the glirids Anthracoglis, Carbomys, Margaritamys, Stertomys, the hamster Hattomys and the murids Mikrotia and Anthracomys). These were excluded from the analyses because, even though their continental ancestors are known in a few instances, they do not occur elsewhere in the study area and would mask the overall pattern because they represent associations of unique composition compared to the mainland ones, and therefore their inclusion might increase artificially the generic diversity at particular periods.

\section{Quality of the fossil record}

Any study on diversity has the danger of being biased by sampling. In the case of our study, this bias takes many forms. For instance, not all $\mathrm{MN}$ zones are of equal length or sampling activity is not equally distributed. Thus, much of the work in the Iberian Peninsula has focussed on the Calatayud-Teruel and Vallès-Penedès basins, whereas in central Europe, the North Alpine Foreland Basin and the surrounding Jura plateau have been extensively explored. Therefore, these areas are overrepresented in the fossil record. Nor are well-sampled localities equally distributed in time. Karstic localities generally require less sampling effort and produce more extensive faunal lists. Then again, a fair number of karstic localities were not included in our analyses, as they could not be with certainty assigned to a single MN unit due to presumed admixture from different time slices. Unfortunately, this is a common situation in karstic sites, with episodes of infilling sometimes separated by remarkably long time spans (e.g., Bolliger and Rummel 1994). Problems with correlation to the MN system play also a role in localities from the eastern Mediterranean and in particular Anatolia. Important markers may be known to appear earlier in the record (Democricetodon, Megacricetodon, Eumyarion, Cricetodon; Van den Hoek Ostende et al. 2015 and references therein), be absent during major periods (Eomyidae) or have ecological counterparts (Hispanomys vs. Byzantinia). This introduces another bias in the dataset, as less localities from that area will have met the prerequisite of being unequivocally assigned to an $\mathrm{MN}$ unit.

Apart from biases inherent to the nature of the fossil record, there are also biases related directly to the construction of the dataset. For instance, the number of taxa entered in the database for each locality may not capture the actual number of taxa collected. If the data derive from a comprehensive paper on one or more localities, faunal lists can be considered as representative of the number of taxa found. But as other studies focus on taxonomic groups, often just the occurrences of this particular group are entered, leaving an incomplete overview of the fauna. As discussed below, this may be the case for MN 5 data from central Europe, where around $30 \%$ of the fauna lists feature only one genus. Another bias introduced by the database itself are faunal lists of localities, for which only older and often outdated literature references are available, or for which literature has not been yet updated.

Peláez-Campomanes and Van der Meulen (2009) tested the data quality of the NOW database, comparing the record 
for the large and the small mammals. In the case of the latter, they considered the record homogeneous, although they noted that the record of MN 12 was problematic. Their results certainly provide a first validation for the present work. However, the geographical area they used for their analysis was the European record west of 20 degrees longitude, roughly coinciding with our central European and Iberian Peninsula (CE and IB) records combined. In the present paper we distinguish subsets IB and CE, and add a third (EM, eastern Mediterranean), which is expected to have a less solid coverage of the fossil record.

In their analyses, Peláez-Campomanes and Van der Meulen (2009) calculated the diversity using rarefaction and the Fisher Alpa index. In order to get a better view on how our dataset behaved, we take here a more empirical method. The highest number of localities is found in MN 5 for central Europe (113) and the Iberian Peninsula (97). Unfortunately, this is a unit with strong diachrony between the two areas, lasting considerably longer in Spain, but this has no direct influence on the discussion, as we are mainly interested in the relation between the number of localities sampled and the overall generic diversity within an $\mathrm{MN}$ unit. We randomized the order of localities and cumulatively counted the generic diversity, as it were sampling one locality at the time. This procedure was repeated ten times for each region and the
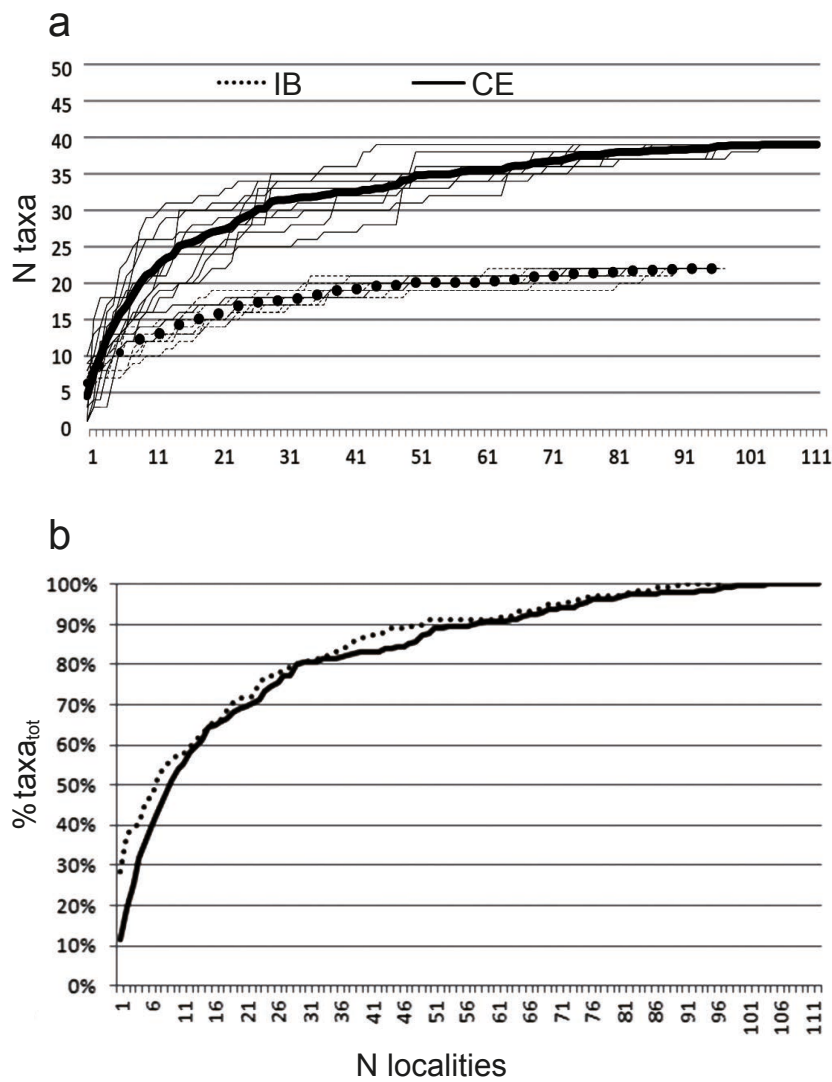

Text-fig. 1. Result of cumulative random counting of MN 5 localities in central Europe and the Iberian Peninsula. Ten simulations were run for each area. a. Results of the count including the average in bold, showing the clearly lower diversity in IB. b. The average lines standardized, showing similar patterns in the two areas. Note that in the simulation around thirty localities were needed to capture $80 \%$ of the regional diversity.
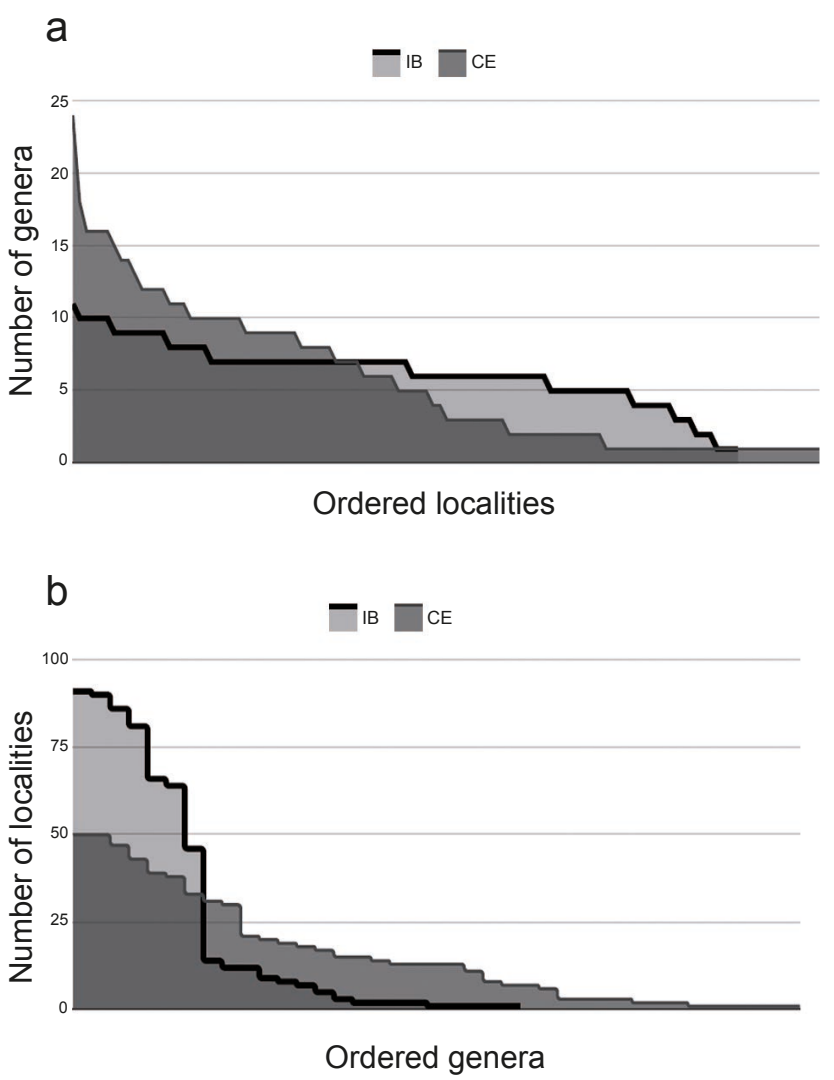

Text-fig. 2. The relation between number of genera and localities in MN 5 of central Europe (CE) and the Iberian Peninsula (IB). a. Localities ordered from highest to lowest number of taxa; the distribution is more equitable in the Iberian Peninsula. b. Genera ordered from most common to rarest; the distribution of genera is more equitable in central Europe. The low number of common genera is an artefact of incomplete faunal lists (see text).

average for all the runs was calculated in Excel. As expected, this results in asymptotic curves (Text-fig. 1a). Iberia shows a clearly lower overall diversity than central Europe. Notably, the initial curve for central Europe is much steeper. However, if we recalculate the curves as percentage of the total diversity, the two are remarkably similar (Text-fig. 1b).

A difference in the slope of diversity curves was also noted by Peláez-Campomanes and Van der Meulen (2009) in their rarefaction approach. These authors considered that indicative of the complexity of factors determining the calculations, including the number of rare taxa or the number of well-defined localities. Text-fig. 2 shows that these two parameters are indeed vastly different for the two areas. In Text-fig. 2a, we ordered the localities according to the number of genera found. Central Europe has one locality (Hambach 6C) that with 24 different rodent genera holds over $60 \%$ of all the rodents found during MN 5 in that area. Localities with such a rich rodent diversity are rare, and the graph gradually slopes down. Notably, one third of the localities $(34 / 103)$ is represented in the database by one rodent genus only. The curve for the Iberian Peninsula is much more equitable. The vast majority of the localities holds six to eight genera and thus per locality around one third of the total number of genera, but, of course, in varying 
compositions. Thus, differences in the behaviour of both curves can be interpreted as differences in the recorded alpha diversity of the localities.

When looking at the occurrences of genera an opposite picture emerges (Text-fig. 2b). The Iberian Peninsula has four genera (Democricetodon, Megacricetodon, Armantomys and Heteroxerus) that appear in almost all the localities, but, beyond these, three quarter of the genera appears in less than $15 \%$ of the localities. Here, the curve for central Europe is far more equitable and does not show a fast drop between the most common and the rare genera. At first sight, a salient feature of the central Europe curve is the much lower attribution of the most common genera, being present in less than $50 \%$ of the total number of localities. It is somewhat surprising to find ubiquitous genera such as Democricetodon or Megacricetodon are represented in such low numbers. This is, however, presumably an artefact from the high number of localities which record only one genus in combination with the equitable distribution of the genera. If we were to consider only localities with more than five genera present, the occurrences would be $90 \%$ of the localities for Democricetodon and $88 \%$ for Megacricetodon. Of course, with increased sampling also the numbers for the other genera would increase leaving the shape of the curve more or less intact; the overall higher alpha diversity per locality in CE compared to IB is considered very real.

Obviously, both curves would change with a larger sampling effort, or, particularly in the case of the central European record, an updating of the faunal list to contain all taxa found. However, updating the dataset would likely have a stronger effect on the occurrences per locality. Localities that record only one or two genera obviously present an incomplete picture and correcting that would lead to steeper curves in Text-fig. 1. Increased sampling would also produce more records of the rarer genera and, as was shown for Democricetodon and Megacricetodon, increase the percentage of the more common taxa. Nevertheless, the more equitable distribution in central Europe versus the dominance of a limited number of genera in Iberia is considered real. The most common genera in Iberia are true residents sensu Van der Meulen et al. (2005), but rarer genera may be residents simply in low numbers or with a smaller chance of being preserved in the fossil record. However, rarity may also be linked to marginality of a population of a larger range.

So is it feasible to indicate a minimum number of localities per $\mathrm{MN}$ zone required to capture diversity in one of the considered regions? The two curves in Text-fig. $1 \mathrm{~b}$ show a similar pattern and suggest that $80 \%$ of the regional diversity is captured by around thirty localities. Nevertheless, these are only two examples and there are simply too many factors that determine the slope of the curve. A minimum number of localities cannot be given with confidence, but for our study areas, it is clear that a substantial number of localities is desirable. We discussed two parameters that influence diversity, but as Peláez-Campomanes and Van der Meulen (2009) indicated, there are more factors. For instance, the heterogeneity of the region in term of palaeoenvironments. We know, for instance, that vast differences can exist between basins only a couple of hundred kilometres apart (Madern et al. 2018). Whereas the number of localities and the sampling effort needed to capture the true diversity is very high and probably not feasible to ever establish, it is also clear that any analysis based on a low number of localities must be considered with the utmost caution. Peláez-Campomanes and Van der Meulen (2009) indicated that, within the range of their analysis ( $\mathrm{MN} 4-\mathrm{MN} 16)$, the small mammal record appeared to be homogeneous with the exception of MN 12. Not surprisingly, this is one of the poorest-represented $\mathrm{MN}$ units in central Europe (seven localities; Text-fig. 3). On the other hand, MN 15 is represented in that region by twelve localities only, yet yielded the single highest generic diversity, emphasizing the complex relationship between sample size and diversity.

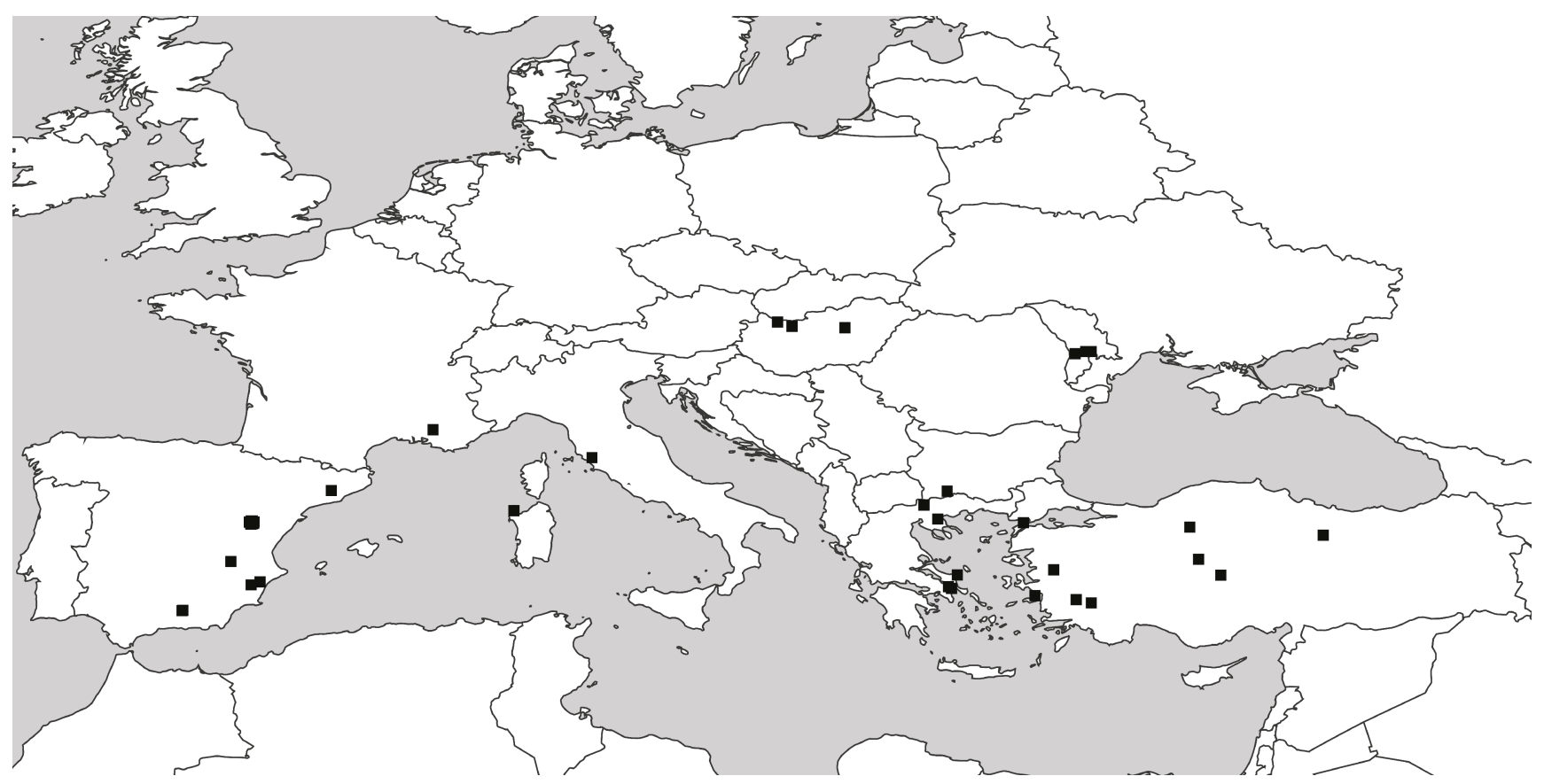

Text-fig. 3. MN 12 localities in the NOW database (The NOW Community 2019). Note that the unit is not represented in major parts of Europe. 


\section{Taxonomic impediment}

Any diversity study is dependent on the quality of the underlying identifications and taxonomy. A study that retrieves its data from any database, will face problems with part of the underlying data coming from early entries based on outdated literature. Having the advantage of a large author group with various specialities, this project led to a large number of emendations to the NOW database. Some of the underlying problems were quite obvious to specialists: the entry of Arvicola in the Pliocene locality of Gundersheim 1 or the presence of Democricetodon in the Pliocene locality of Węże 1. The latter, for instance, dates back to a paper by Fahlbusch (1969), before we recognized the restricted stratigraphic range of Democricetodon. There is, however, a big risk in analyses that are done without the benefit of critical review by specialists. One of the other "obvious" errors lay with the data entry of Armantomys, a Miocene endemic to southwestern Europe, in central European Pliocene localities. Such errors have been corrected, but notably, the presumed long range of Armantomys led Liow et al. (2008) to assume it was a long-lived genus. Their assertion that it involved an eomyid, whereas Armantomys is a glirid, validates the point that taxonomic expertise is of great importance in obtaining reliable results from diversity studies or indeed any other study whose source is a large database.

We should stress at this point that databases are invaluable tools for diversity studies and that, of course, the vast majority of the data has a very solid basis. But between the reliable data and the obvious errors there is a gray area. For example, beaver taxonomy has been confusing and we have made some corrections following Casanovas-Vilar and Alba (2011). However, in all likelihood, post-MN 7+8 citations of Steneofiber most likely correspond to Chalicomys, as do pre-MN 13 citations of Castor. Such generalisation can, of course, not be made without a revision of the material.

Looking at it from a geographical point of view, there may be a bias in the data. For instance, basins such as the North Alpine Foreland Basin or the Vallès-Penedès have very early citations in literature. However, continuous research will have revised many problems stemming from the older literature. In the eastern Mediterranean, many classical localities have remained untouched for decades. The Slovak locality of Ivanovce is, for instance, currently under review (Fejfar and Sabol 2004, Fejfar et al. 2012, 2015). Many of the problems we encountered involved other localities from the same general area and time (Węże, Podlesice) and is clear that a major revision for these sites is also necessary. As a temporary solution, we have not taken into account the most questionable identifications, such as the presence of Rattus, Miodyromys, Thallomys and Parapodemus in MN 16 or a record of Microtus in MN 13, without, however, correcting these data in the NOW database for now.

\section{Generic diversity}

Text-fig. 4 shows the total number of rodent genera per MN zone for each of the regions. Most obvious is the overall higher diversity in central Europe. A similar pattern was found for the insectivores by Furió et al. (2011).

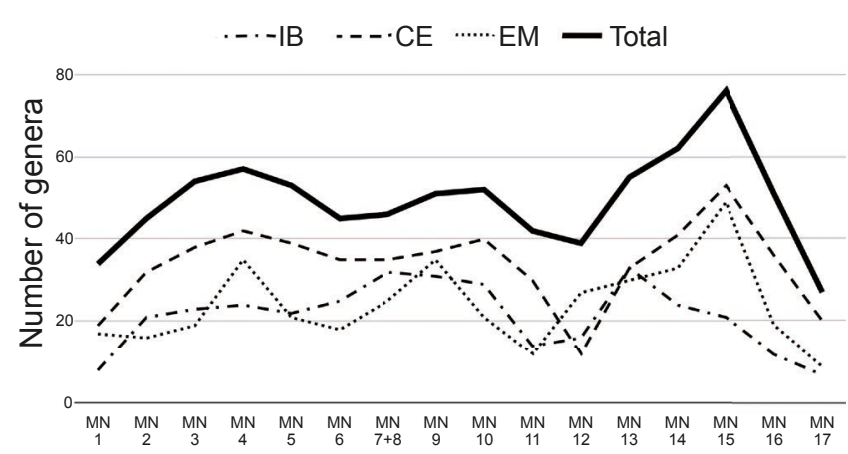

Text-fig. 4. Neogene generic diversity in rodents for the three study areas separately and combined.

These authors explained the higher number of taxa on high latitudes by a precipitation gradient. Indeed, if throughout the Neogene the more northern areas were more forested, they would have offered a larger number of niches for rodents as well. Still, other explanations must be considered as well, such as the heterogeneity of environments in the different regions. In the case of Iberia, we must also consider the Peninsula effect (e.g., Baquero and Telleria 2001). This is most apparent in MN 15, in which both central Europe and the eastern Mediterranean score their highest values (56 and 50 genera, respectively), whereas the mere 21 genera in the Iberian Peninsula fit an overall trend of decrease in the late Neogene.

Looking at the overall trends, it is clear that all areas start with a low number of genera in MN 1. This could be, at least in part, a sampling issue, as MN 1 localities are relatively few ( $\mathrm{N}=10,10$ and 4 for IB, CE and EM, respectively). On the other hand, the end of the Oligocene saw the disappearance of a number of rodent (sub-)families, such as the Theridomyidae. So, alternatively, the low number of genera could reflect a recuperation phase, or be the result of a drastic change in environments throughout western Eurasia at the Oligocene/Miocene boundary.

The lack of change at the MN 3/MN 4 transition in both central Europe and the Iberian Peninsula is remarkable. A major change at this transition is the entrance of a number of cricetines, that quickly dominate the faunas. Yet the overall number of genera present does not seem to be affected. The more remarkable is that there is a marked rise in the eastern Mediterranean. The turnover involved the entrance of cricetin taxa in western Europe, ending the so-called Cricetid Vacuum. These taxa were, however, already present in the eastern Mediterranean during most of the early Miocene. In part, the rise may be related to sampling. MN 3 is represented in the eastern Mediterranean by two major localities only, Sabuncubeli and Keseköy. Nevertheless, also MN 4 is not well represented in the area and the main contributors are the diversity-rich localities of Aliveri and Karydia. Thus, it seems plausible that the faunal turnover, which is caused by a faunal exchange between east and west, had a stronger effect on the composition of the faunas in the eastern Mediterranean. Possibly the opening of the landscape resulted in a mosaic in available niches and a temporary increase in the number of taxa, which was followed by a decrease as the forests gave way to more open habitats. 
In the Iberian Peninsula, we see an increase in the number of taxa in $\mathrm{MN} 7+8$ or, in regional stratigraphy, the late Aragonian. This increase is related to more humid conditions in the area at the onset of the Vallesian. Notably, MN 7+8 is the longest $\mathrm{MN}$ unit in the region, so a more detailed study would be needed to see in more detail when the increase occurred exactly. The period sees an overall southward shift of the ecosystems in western Eurasia (Madern and Van den Hoek Ostende 2015) that also led to a smaller difference in the number of taxa at higher and lower latitudes. Notably, the number of rodent taxa in the Vallesian shows a minor decrease with respect to the latest Aragonian. Many of the genera typically associated with the early Vallesian had already made their entry, particularly in the Vallès-Penedès, when genera from central Europe extended to lower latitudes to build a diversity hotspot in that basin (Madern and Van den Hoek Ostende 2015). By contrast, diversity peaked in the eastern Mediterranean at the beginning of the Vallesian, dropping sharply again in the late Vallesian (MN 10). In the Iberian Peninsula, the decrease in diversity between MN 9 and MN 10 was minor. Notably, this period has appeared in literature as the Vallesian Crisis, but Casanovas-Vilar et al. $(2014,2016)$ already noted that this crisis in the VallèsPenedès is less severe and more gradual than previously assumed, resulting mainly from a sampling bias between the early and late Vallesian.

The drop in diversity between MN 9 and MN 10 in the eastern Mediterranean is followed by a similar drop between MN 10 and MN 11 in central Europe and the Iberian Peninsula. This is the beginning of the Turolian. The dryer conditions of the period presumably affected the east earlier than the west, explaining the different timing of the diversity decrease. The severe drop in central Europe between MN 11 and MN 12 is presumably controlled by sampling, late Miocene localities being notably rare in the northern parts of Europe. The problems with the record for MN 12 were already noted by PeláezCampomanes and Van der Meulen (2009). The low number of genera for the Iberian Peninsula is somewhat surprising, given the extensive sampling of this period in the Teruel Basin (Van Dam et al. 2001). However, we need to bear in mind that despite the excellent local record, it may not represent the overall diversity in Spain, and the absence of extensive records from other basins, such as the Vallès-Penedès, may in part explain this regional low. The eastern Mediterranean record for this period is problematic, as the correlation to the MN system for the Turolian is somewhat problematic. The low for MN 11, which features only four localities in the region, can certainly be attributed to sample size.

During MN 13, dry conditions prevailed in southern Europe. Nevertheless, we note a sharp increase in the number of genera in the Iberian Peninsula. In part, this may include African immigrants in this period. In addition, the latest part of the Messinian, the Ventian, already sees the appearance of a number of Pliocene genera, which suggests that typically Pliocene genera may indeed appear at the very end of the Miocene. As such, the increase mirrors the situation at the end of the Aragonian, where we noted the early appearance of "Vallesian" genera led to a higher richness even before the Vallesian per se started.

As noted before, the Pliocene curve for the Iberian Peninsula shows a decrease, which could be related to the Peninsula effect. Eastern and central Europe show a peak. After MN 15, the number of genera decreases in all three areas. Although this will be certainly related to the cooler conditions towards the Quaternary, the strong decrease already in the later part of the Pliocene is somewhat surprising. The Pliocene optimum in generic diversity is almost certainly related in part to the very favourable, forested conditions early in the epoch. However, this alone cannot explain the peak, as forested conditions are also found in the early Miocene and Vallesian. In addition to an increase of wooded environments, the heterogeneity of the landscape may also play a role. Diversity in a wider region would certainly increase if it encompasses both forested and more open terrain. Madern and Van den Hoek Ostende (2015) suggested that diversity peaks in the fossil record are found mostly at the boundary between different environments. The low diversity in the Iberian Peninsula may well reflect less habitat variation throughout the area.

\section{Taxonomic composition}

Throughout the Neogene, rodent faunal composition rapidly changes. For this reason, the rodents make excellent stratigraphic markers. The stratigraphy is mainly based on the Muridae sensu lato, which is as a rule the most abundant group in the fossil assemblages and also the group with the fastest evolutionary changes. Murids include a vast array of dental morphologies distributed around a limited amount of dental plans that, in extant species, correspond roughly to the grouping based on molecular phylogenies but that when including the extinct forms become much more difficult to interpret phylogenetically based just on dental morphology. The arvicoline, murine or cricetine molars do indeed look completely different and are to the palaeontologist easily identified to date sediments. Murines, for instance, dispersed into Europe at the beginning of the late Miocene, arvicolines appeared at the start of the Pliocene. Both dental morphologies are derived from a basic cricetine molar. Here lies the basis of some of the taxonomic difficulties in fossil rodents, the cricetine molar representing one of the crown groups as well as a stem group. Whereas the NOW database follows a more detailed classification, in this section we lump primitive groups bearing a cricetine molar with true cricetines, aware that at best this represents a paraphyletic grouping.

Looking at the proportion of the different families to generic diversity, it is clear that the dominance of murids in the Neogene assemblages is not mirrored in the number of genera (Text-fig. 5). Up to the end of the middle Miocene, the Gliridae is by far the most diverse family in all regions. A notable exception is the early Miocene of the eastern Mediterranean with fewer glirids but more cricetines. In part, this reflects the regional appearance in Anatolia of genera such as Eumyarion, Democricetodon and Megacricetodon long before they reach Europe. However, the strong dominance in the number of genera may well be an artefact. Bearing in mind the low number of localities and comparing the Anatolian early Miocene to the Iberian middle Miocene, where these hamsters are also dominant, it seems probable that the diversity of glirids is as yet underrepresented in the Anatolian record. Nevertheless, we need to bear in mind that Anatolia represented a different bioprovince at the time, as shown by the total absence of eomyids, and therefore may 
IB

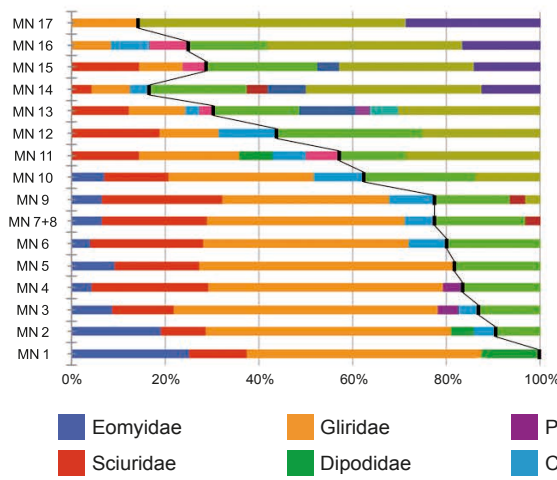

CE

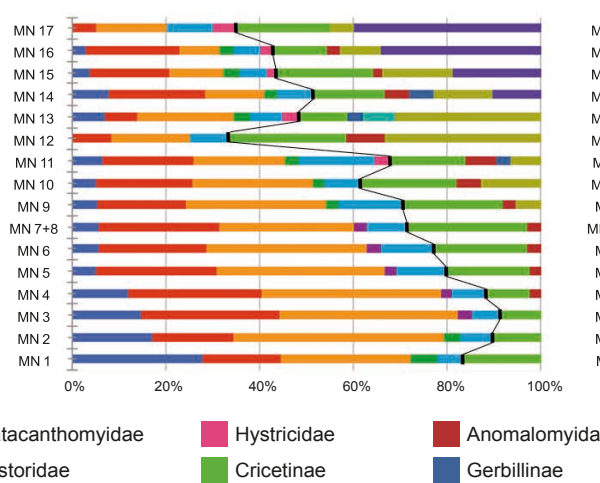

EM

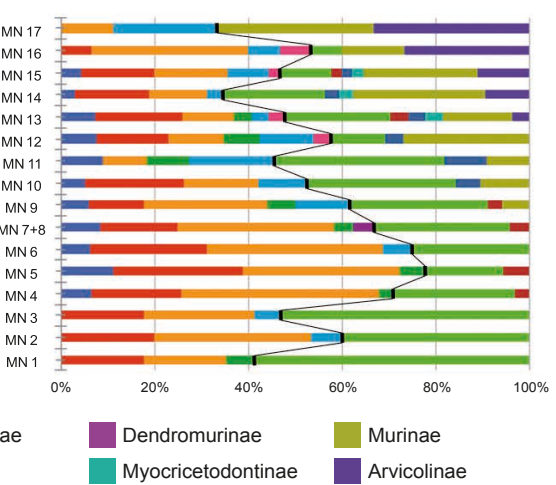

Text-fig. 5. The generic composition of the rodent faunas on the family and subfamily level. The black line sets apart subfamilies of the Muridae (right side) from other rodents (left). The proportion of murid genera increases over time.

also have had its own, more limited, glirid fauna. Only additional sampling can answer this.

After the middle Miocene, we see a gradual decline of the glirids and at the same time the murids start to take up an increasingly larger portion of the generic diversity. Considering the murids separately, we notice that the cricetines are somewhat on the decline in the later part of the Neogene. Only in central Europe, cricetines peak again in the Pliocene, which mainly reflects the success of microtoid genera such as Baranomys, Celadensia and Bjornkurtenia, the taxonomy of which is complicated (Fejfar et al. 2011). The cricetines do not seem to be directly affected by the appearance of the murines at the beginning of the late Miocene or the entrance of arvicolines at the start of the Pliocene, nor do we see a decline of the murines when the arvicolines appear. When comparing the regions, it is clear that the arvicolines play a far greater role in central Europe than in the more southern regions (Text-fig. 5). This seems to fit the current, more northern distribution of the subfamily, being more adapted to temperate climates. This preference of the arvicolines for more temperate climates compared to cricetines and murines could be also the explanation for the decline of these two latter groups in MN 16 and MN 17, meanwhile arvicolines show a more or less constant diversity on each zone (Text-fig. 5), related to the decline in temperature occurred on those units. An interesting phenomenon occurs in the Iberian Peninsula where murid diversity is highest in $\mathrm{MN} \mathrm{13}$. This is related with the African influence during that time, as dendromurines, gerbillines and myocricetodontines enter the Peninsula.

So the development of new dental morphologies in the murids leads to an accumulation of generic diversity (up to 30 genera in MN 15) rather than a replacement (Text-fig. 5). This will be a major factor in the generic optimum in the early Pliocene, where the three major groups of murids, cricetines, murines and arvicolines, are dominant. However, exploring the evolutionary drivers behind the increase in dental morphologies is beyond the scope of the present paper.

\section{Conclusions}

This project set out as a simple overview of generic diversity in rodents to show how much has been accomplished since Gerhard Storch started his career and his contributions to the fossil record of small mammals. It is, however, evident that there is nothing simple about diversity and that this overview only touches the fringes of a complex system. A general picture emerges, but we are only at the beginning of understanding the interplay of all the factors behind diversity changes.

One of the attractions of small mammal palaeontology is the vast amount of data which are nowadays available. At the same time, this presents one of the great challenges. We cannot take our data for granted. This involves the taxonomy which, as an expertise, seems to be considered less and less fancy and is therefore receiving less attention. Still, it is at the very base of any analysis and we need to scrutinize our data for outdated identifications or note issues that are clearly unsatisfactorily resolved. In this respect, we mentioned beaver taxonomy as an example. Also, different classifications will have repercussions for the outcome. Whether or not species are congeneric or should be separate is to a large extent a choice and specialists do not agree on the classification that best represents the true diversity. Another aspect is the completeness of our dataset. We noted that in a subset in which many localities were represented by one taxon only, recorded occurrences of very common taxa decline. The third major aspect is the time scale. The biochronological MN system as yet still seems the best compromise for long distance analyses, but as regional stratigraphies develop, so the correlations to the system or to the absolute time scale may improve; databases need to be updated for stratigraphy. Ultimately, diversity studies like this one cannot yield detailed results based on the MN system only. For instance, one of the major questions would be how the Mid-Miocene Climatic Optimum and subsequent cooling affected diversity throughout the study area. Given the strong diachronies in the MN system during the middle Miocene, this event is presumably represented in different $\mathrm{MN}$ zones for the different regions, making it impossible to accurately record the changes in diversity at that time. In short, we always need to consider that patterns found in biodiversity analyses could be an artefact of the dataset rather than a signal with biological meaning.

Within our dataset, we confirmed that the small mammal record for MN 12 is insufficient. In addition, MN units 1 and 17 in our dataset seem to be underrepresented, either by true lack of localities or by lack of entries. The remaining record for the Iberian Peninsula and central Europe appears to be good to excellent, but the eastern Mediterranean record 
contains as yet many uncertainties. These uncertainties both spring from a limited number of localities and unresolved stratigraphic relations.

Considering the retrieved pattern, the generic diversity curve for the Miocene is surprisingly constant, considering the vast changes that took place during that epoch. There are some indications for biodiversity highs during the MidMiocene Climatic Optimum and the Vallesian, and a limited decline at the Mid-Miocene Cooling. Heightened diversity during $\mathrm{MN} \mathrm{7+8}$ and $\mathrm{MN} 13$ presumably is the result of the presence in these units of representatives of typical forms from following or preceding units (Vallesian and Ventian faunas). Diversity changes should be monitored at a smaller time scale to determine if they don't in fact represent very rapid increases at the very end of the units.

The most conspicuous biodiversity optimum takes place in the early Pliocene. This is related to the favourable environments at the time, in particular to the development of the late Neogene floras, and the increase in habitat diversity related to an increase in rodent biodiversity, and more specifically in dental morphologies, in the murids.

Looking at the differences between the different regions, it is clear that diversity is highest at the higher latitudes of central Europe. The lower numbers for the eastern Mediterranean may in part be related to the lower number of localities from that area. By contrast, the overall fossil record of the Iberian Peninsula is excellent and the lower diversity is considered real. The curve for the region (Text-fig. 4) shows a clear local optimum during the Vallesian, which can be related to the rich record from the Vallès-Penedès at the time. A second peak occurs in MN 13, which will represent the influence of African faunas during the Messinian Crisis. Notably, the Pliocene peak found in central Europe and the eastern Mediterranean is not found in Iberia. In interpreting the diversity of the region, the peninsula effect must be taken into account.

\section{Acknowledgements}

We are most grateful to the initiators of this volume in honour of Gerhard Storch. The authors would like to thank the reviewers Dr. L. Flynn and Dr. C. Gibert by their valuable comments that significantly improved this work. PJ and MB were supported financially by the Slovak Research and Development Agency under the contracts No. APVV160121, APVV-15-0575 and by the Scientific Grant Agency of the Ministry of Education, Science, Research and Sport of the Slovak Republic and the Slovak Academy of Sciences (VEGA) under the contract No. VEGA 1/0702/17. The contributions of ICV and SJV were funded by the Agencia Estatal de Investigación from the Spanish Ministeriode Economía, Industria y Competitividad and the Agencia Estatal de Investigación (AEI) from Spain/European Regional Development Fund of the European Union (projects CGL2017-82654-P and CGL2016-76431-P and RYC-201312470 research contract to ICV), by the Agència de Gestió d'Ajuts Universitaris i de Recerca of the Generalitat de Catalunya (2018FI B1 00201 predoctoral grant to SJV), and by the CERCA programme of the Generalitat de Catalunya. SJV and ICV are members of the consolidated research group 2017 SGR 116 of the Generalitat de Catalunya.

\section{References}

Abdul Aziz, H., Böhme, M., Rocholl, A., Prieto, J., Wijbrans, J. R., Bachtadse, V., Ulbig, A. (2010): Integrated stratigraphy and ${ }^{40} \mathrm{Ar} /{ }^{39} \mathrm{Ar}$ chronology of the early to middle Miocene Upper Freshwater Molasse in western Bavaria (Germany). - International Journal of Earth Sciences, 99: 1859-1886. https://doi.org/10.1007/s00531-009-0475-8

Abdul Aziz, H., Böhme, M., Rocholl, A., Zwing, A., Prieto, J., Wijbrans, J. R., Heissig, K., Bachtadse, V. (2008): Integrated stratigraphy and ${ }^{40} \mathrm{Ar} /{ }^{39} \mathrm{Ar}$ chronology of the Early to Middle Miocene Upper Freshwater Molasse in eastern Bavaria (Germany). - International Journal of Earth Sciences, 97: 115-134. https://doi.org/10.1007/s00531-006-0166-7

Agustí, J., Cabrera, L., Garcés, M., Krijgsman, W., Oms, O., Parés, J. M. (2001): A calibrated mammal scale for the Neogene of Western Europe. State of the art. - EarthScience Reviews, 52: 247-260. https://doi.org/10.1016/S0012-8252(00)00025-8

Baquero, R. A., Telleria, J. L. (2001). Species richness, rarity and endemicity of European mammals: a biogeographical approach. - Biodiversity and Conservation, 10: 29-44. https://doi.org/10.1023/A:1016698921404

Blanco, F., Gómez Cano, A. R., Cantalapiedra, J. L., Domingo, M. S., Domingo, L., Menéndez, I., Hernández Fernández, M. (2018): Differential responses of Miocene rodent metacommunities to global climatic changes were mediated by environmental context. - Scientific Reports, 8: 2502 (12 pp.). https://doi.org/10.1038/s41598-018-20900-5

Bolliger, T., Rummel, M. (1994): Säugetierfunde aus Karstspalten - Die komplexe Genese am Beispiel eines Steinbruches bei Petersbuch, südliche Frankenalb (Bayern). Mitteilungen der Bayerischen Staatssammlung für Paläontologie und historische Geologie, 34: 239-264.

Casanovas-Vilar, I., Alba, D. M. (2011): The never-ending problem of Miocene beaver taxonomy. - Acta Palaeontologica Polonica, 56: 217-220.

http://dx.doi.org/10.4202/app.2010.0051

Casanovas-Vilar, I., Alba, D. M., Garcés, M., Robles, J. M., Moyà-Solà, S. (2011): Updated chronology for the Miocene hominoid radiation in Western Eurasia. - Proceedings of the National Academy of Sciences, 108: 5554-5559. https://doi.org/10.1073/pnas.1018562108

Casanovas-Vilar, I., García-Paredes, I., Alba, D. M., Van den Hoek Ostende, L. W., Moyà-Solà, S. (2010): The European far west: Miocene mammal isolation, diversity and turnover in the Iberian peninsula. - Journal of Biogeography, 37: 1079-1093. https://doi.org/10.1111/j.1365-2699.2010.02286.x

Casanovas-Vilar, I., Madern, A., Alba, D. M., Cabrera, L., García-Paredes, I., Van den Hoek Ostende, L. W., DeMiguel, D., Robles, J. M., Furió, M., Van Dam, J., Garcés, M., Angelone, C., Moyà-Solà, S. (2016): The Miocene mammal record of the Vallès-Penedès Basin (Catalonia). - Comptes Rendus Palevol, 7(15): 791-812. https://doi.org/10.1016/j.crpv.2015.07.004 
Casanovas-Vilar, I., Van den Hoek Ostende, L. W., Furió, M., Madern, P. A. (2014): The range and extent of the Vallesian Crisis (Late Miocene): new prospects based on the micromammal record from the Vallès-Penedès basin (Catalonia, Spain). - Journal of Iberian Geology, 40: 29-48. https://doi.org/10.5209/rev_JIGE.2014.v40.n1.44086

Crusafont Pairó, M., de Villalta, J. F., Bataller, J. R. (1948): Los castores fósiles de España [The fossil beavers of Spain]. - Boletín del Instituto Geológico y Minero de España, 61: 321-349. (in Spanish)

De Bruijn, H., Daams, R., Daxner-Höck, G., Fahlbusch, V., Ginsburg, L., Mein, P., Morales, J. (1992): Report of the RCMNS working group on fossil mammals, Reisensburg 1990. - Newsletters on Stratigraphy, 26(2-3): 65-118. https://doi.org/10.1127/nos/26/1992/65

Dehm, R. (1935): Über tertiäre Spaltenfüllungen im Fränkischen und Schwäbischen Jura. - Abhandlungen der Bayerischen Akademie der Wissenschaften, mathematisch-naturwissenschaftliche Klasse, Neue Folge, 29: $1-82$.

Fahlbusch, V. (1969): Pliozäne und Pleistozäne Cricetinae (Rodentia, Mammalia) aus Polen. - Acta Zoologica Cracoviensia, 14: 99-137.

Fejfar, O., Heinrich, W.-D., Kordos, L., Maul, L. C. (2011): Microtoid cricetids and the early history of arvicolids (Mammalia: Rodentia). - Palaeontologia Electronica, 14(3): 27-38.

Fejfar, O., Sabol, M. (2004): Pliocene carnivores (Carnivora, Mammalia) from Ivanovce and Hajnáčka (Slovakia). Courier Forschungs-Institut Senckenberg, 246: 15-53.

Fejfar, O., Sabol, M., Ďurišová, A. (2015): Pliocene vertebrates from Ivanovce and Hajnáčka (Slovakia). IX. A small-sized cervoid pecoran from Ivanovce. - Neues Jahrbuch für Geologie und Paläontologie, Abhandlungen, 275(3): 347-356. https://doi.org/10.1127/njgpa/2015/0468

Fejfar, O., Sabol, M., Tóth, C. (2012): Early Pliocene vertebrates from Ivanovce and Hajnáčka (Slovakia). VIII. Ursidae, Mustelidae, Tapiridae, Bovidae and Proboscidea from Ivanovce. - Neues Jahrbuch für Geologie und Paläontologie, Abhandlungen, 264(2): 95-115. https://doi.org/10.1127/0077-7749/2012/0231

Furió, M., Casanovas-Vilar, I., Van den Hoek Ostende, L. W. (2011): Predictable structure of Miocene insectivore (Lipotyphla) faunas in Western Europe along a latitudinal gradient. - Palaeogeography, Palaeoclimatology, Palaeoecology, 304(3-4): 219-229.

https://doi.org/10.1016/j.palaeo.2010.01.039

García-Paredes, I., Álvarez-Sierra, M. Á., Van den Hoek Ostende, L. W., Hernández-Ballarín, V., Hordijk, K., López-Guerrero, P., Oliver, A., Peláez-Campomanes, P. (2016): The Aragonian and Vallesian high resolution micromammal succession from the Calatayud-Montalbán Basin (Aragón, Spain). - Comptes Rendus Palevol, 15: 781-789. https://doi.org/10.1016/j.crpv.2015.09.014

Hír, J., Venczel, M., Codrea, V., Angelone, C., Van den Hoek Ostende, L. W., Kirscher, U., Prieto, J. (2016): Badenian and Sarmatian s.str. from the Carpathian area: Overview and ongoing research on Hungarian and Romanian small vertebrate evolution. - Comptes Rendus Palevol, 15, 863-875.

https://doi.org/10.1016/j.crpv.2016.08.001

Hír, J., Venczel, M., Codrea, V., Rösner, G., Angelone, Ch., Van den Hoek Ostende, L., Rosina V., Kirscher, U., Prieto, J. (2017): Badenian and Sarmatian s. str. from Carpathian area: Taxonomical notes concerning the Hungarian and Romanian small vertebrates and report on the ruminants from the Felsőtárkány Basin. - Comptes Rendus Palevol, 16: 312-332.

https://doi.org/10.1016/j.crpv.2016.11.006

Lartet, E. (1851): Notice sur la colline de Sansan, suivie d'une récapitulation des diverses espèces d'animaux vertébrés fossiles, trouvés soit à Sansan, soit dans d'autres gisements du terrain tertiaires du miocène dans le bassin sous pyrénéen. - J. A. Portes, Auch, 47 pp.

Liow, L. H., Fortelius, M., Bingham, E., Lintulaakso, K., Mannila, H., Flynn, L., Stenseth, N. C. (2008): Higher origination and extinction rates in larger mammals. Proceedings of the National Academy of Sciences of the USA, 105: 6097-6102. https://doi.org/10.1073/pnas.0709763105

Madern, P. A., Van de Put, J. M. M. S., Casanovas-Vilar, I., Van den Hoek Ostende, L. W. (2018): Iberian micromammals show local extent of Vallesian Crisis. - Palaeogeography, Palaeoclimatology, Palaeoecology, 496: 18-31. https://doi.org/10.1016/j.palaeo.2017.12.033

Madern, P. A., Van den Hoek Ostende, L. W. (2015): Going south: Latitudinal change in mammalian biodiversity in Miocene Eurasia. - Palaeogeography, Palaeoclimatology, Palaeoecology, 424: 123-131.

https://doi.org/10.1016/j.palaeo.2015.02.011

Mein, P. (1975): Résultats du Groupe de Travail des Vertèbres. - In: Seneš, J. (ed.), Report on Activity of R. C. M. N. S. Working Groups. Regional Committee on Mediterranean Neogene Stratigraphy, Bratislava, pp. 78-81.

Mein, P. (1990): Updating the MN zones. - In: Lindsay, H., Fahlbusch, W., Mein, P. (eds), European Neogene Mammalian Chronology (NATO ASI Series a Life Sciences, 180). Plenum Press, New York, pp. 73-90. https://doi.org/10.1007/978-1-4899-2513-8_6

Meyer, H. von (1846): [Mitteilungen an Professor Bronn]. Neues Jahrbuch für Mineralogie, Geognosie, Geologie und Petrefakten-Kunde, 1846: 462-476

Montuire, S., Maridet, O., Legendre, S. (2006): Late Miocene-Early Pliocene temperature estimates in Europe using rodents. - Palaeogeography, Palaeoclimatology, Palaeoecology, 238: 247-262.

https://doi.org/10.1016/j.palaeo.2006.03.026

Peláez-Campomanes, P., Van der Meulen, A. J. (2009): Diversity of mammals in the Neogene of Europe: comparing data quality of large and small mammals in the NOW database. - Hellenic Journal of Geosciences, 44: 105-115.

Prieto, J., Rummel, M. (2016): Some considerations about the small-mammal evolution in South Germany, with emphasis on late Burdigalian-earliest Tortonian (Miocene) cricetid rodents. - Comptes Rendus Palevol, 15: 837-854.

https://doi.org/10.1016/j.crpv.2016.08.002 
Schaub, S. (1925): Die hamsterartigen Nagetiere des Tertiärs und ihre lebenden Verwandten. - Abhandlungen der Schweizerischen Paläontologischen Gesellschaft, 45: $1-112$.

Schlosser, M. (1902): Beiträge zur Kenntnis der Säugetierreste aus den süddeutschen Bohnerzen. - Geologische und Paläontologische Abhandlungen, 9: 117-258.

Schreuder, A. (1943): Fossil voles and mammals (Desmana, Talpa, Equus, etc.) out of well-borings in the Netherlands. - Verhandelingen van het Geologisch Mijnbouwkundig Genootschap voor Nederland en Koloniën, Geologische Serie, 13: 399-434.

Schreuder, A. (1950): Microtinae from the middle gravels of Swanscombe. - Annals and Magazine of Natural History, Ser. 12, 3: 629-635. https://doi.org/10.1080/00222935008654086

Storch, G. (1978): Die turolische Wirbeltierfauna von Dorn-Dürkheim, Rheinhessen (SW-Deutschland) 2. mammalia: Insectivora. - Senckenbergiana lethaea, 58: 421-449.

Storch, G. (1996): Paleobiology of Messel erinaceomorphs. Palaeovertebrata, 25: 215-224.

Storch, G., Qiu, Z. (1990): Insectivores (Mammalia, Erinaceidae, Soricidae, Talpidae) from the Lufeng hominoid locality, Late Miocene of China. - Geobios, 24: 601-621. https://doi.org/10.1016/0016-6995(91)80025-U

Storch, G., Qiu, Z. (2002): First Neogene Marsupial from China. - Journal of Vertebrate Paleontology, 22: 179-181. https://doi.org/10.1671/0272-4634(2002)022[0179:FNMFC]2.0.CO;2

The NOW Community (2019): New and Old Worlds Database of Fossil Mammals (NOW). Licensed under CC BY 4.0.

Van Dam, J. A., Abdul Aziz, H., Álvarez Sierra, M. A., Hilgen, F. J., Van den Hoek Ostende, L. W., Lourens, L. J., Mein, P., Van der Meulen, A. J., Pelaez-Campomanes, P. (2006): Long-period astronomical forcing of mammal turnover. - Nature, 443: 687-691. https://doi.org/10.1038/nature05163

Van Dam, J. A., Alcalá, L., Alonso Zarza, A. M., Calvo, J. P., Garcés, M., Krijgsman, W. (2001): The Upper Mio- cene mammal record from the Teruel-Alfambra region (Spain). The MN system and continental stage/age concepts discussed. - Journal of Vertebrate Paleontology, 21: $367-385$.

https://doi.org/10.1671/0272-4634(2001)021[0367:TUMMRF]2.0.CO;2

Van Dam, J. A., Weltje, G. J. (1999): Reconstruction of the Late Miocene climate of Spain using rodent palaeocommunity successions: an application of end member modelling. - Palaeogeography, Palaeoclimatology, Palaeoecology, 151: 267-305. https://doi.org/10.1016/S0031-0182(99)00015-2

Van den Hoek Ostende, L. W., Mayda, S., Oliver, A., Madern, A., Hernández-Ballarín, V., Peláez-Campomanes, P. (2015): Aliveri revisited, a biogeographical appraisal of the early Miocene mammals from the eastern Mediterranean. - Palaeobiodiversity and Palaeoenvironments, 95(3): 271-284. https://doi.org/10.1007/s12549-015-0199-7

Van der Meulen, A. J., García-Paredes, I., Álvarez-Sierra, M.A., Van den Hoek Ostende, L. W., Hordijk, K., Oliver, A., López-Guerrero, P., Hernández-Ballarín, V., Peláez-Campomanes, P. (2011): Biostratigraphy or biochronology? Lessons from the Early and Middle Miocene small mammal events in Europe. - Geobios, 44: 309-321. https://doi.org/10.1016/j.geobios.2010.11.004

Van der Meulen, A. J., García-Paredes, I., Álvarez-Sierra, M. A., Van den Hoek Ostende, L. W., Hordijk, K., Oliver, A., Peláez-Campomanes, P. (2012): Updated Aragonian biostratigraphy: small mammal distribution and its implications for the Miocene European chronology. - Geologica Acta, 10: 159-179.

Van der Meulen, A. J., Peláez-Campomanes, P., Levin, S. A. (2005): Age structure, residents, and transients of Miocene rodent communities. - American Naturalist, 165: $108-125$.

https://doi.org/10.1086/428683 